\title{
Keterampilan Menulis Laporan Penelitian Tindakan Kelas Guru di Kecamatan Plered Purwakarta
}

\author{
Rayi Siti Fitriani, Yudi Bachtiar, Gia Nikawanti
}

\author{
STKIP Purwakarta \\ rayivee@gmail.com,
}

\section{Article History}

accepted 24/09/2019

\begin{abstract}
The teacher is an element that plays an important role in improving the quality of education in Indonesia. It is inevitable that there are various problems in learning that need to be solved by a teacher, one of them with research. Classroom Action Research is an attempt to correct any shortcomings and deficiencies in learning. Followed by writing a Classroom Action Research Report, carried out as an attempt to think and prove to improve the professionalism of teachers and is no less important as an added value in increasing credit. The aim of this study is to describe: teacher skills in writing Classroom Action Research reports and obstacles for teachers in writing scientific articles. This research is a qualitative research with a descriptive design. Based on the results of the study, it was concluded that the skills to write research reports in the classroom were still low and very rarely performed. The obstacles that the teacher encountered were the lack of understanding of scientific articles, little systematic writing knowledge, limited liability, problems with the use of computers and time. But of all that, the cause of the obstacles that the teacher encounters is motivation.
\end{abstract}

Keywords: teacher, writing skills, classroom action research report

\begin{abstract}
Abstrak
Penelitian Tindakan Kelas merupakan upaya dalam memperbaiki segala kekurangan dan ketidaksempurnaan dalam pembelajaran yang dapat dilakukan oleh seorang guru. Dilanjutkan dengan melakukan penulisan Laporan Penelitian Tindakan Kelas yang dilakukan sebagai upaya refleksi dan bukti untuk meningkatkan keprofesional guru dan tidak kalah penting lainnya ialah sebagai nilai tambah dalam peningkatan angka kredit. Penelitian ini bertujuan untuk mendeskripsikan: keterampilan guru dalam menulis laporan Penelitian Tindakan Kelas dan hambatan guru dalam menulis karya ilmiah. Penelitian ini merupakan penelitian kualitatif dengan desain deskriptif. Berdasarkan hasil penelitian, disimpulkan bahwa keterampilan menulis laporan penelitian tindakan kelas masih rendah dan sangat jarang dilakukan. Hambatan yang ditemui guru yaitu ketidak pahaman mengenai karya tulis ilmiah, pengetahuan sistematika penulisan yang rendah, keterbatasan lieteratur, kesulitan dalam penggunaan komputer, dan waktu. Namun dari itu semua bahwa yang menjadi akar hambatan yang ditemui oleh guru ialah motivasi.
\end{abstract}

Kata kunci: guru, keterampilan menulis, laporan PTK

Social, Humanities, and Education Studies (SHEs): Conference Series https://jurnal.uns.ac.id/shes

p-ISSN 2620-9284

e-ISSN 2620-9292 


\section{PENDAHULUAN}

Menurut UU No. 14 Tahun 2005 pasal 1 ayat 1, "Guru adalah pendidikan profesional dengan tugas utama mendidik, mengajar, membimbing, mengarahkan, melatih, menilai, dan mengevaluasi peserta didik pada pendidikan anak usia dini jalur pendidikan formal, pendidikan dasar, dan pendidikan menengah". Selanjutnya dijelaskan dalam UU No. 14 tahun 2005 pada pasal 1 ayat 10 disebutkan bahwa "kompetensi adalah seperangkat pengetahuan, keterampilan, dan perilaku yang harus dimiliki, dihayati, dan dikuasai oleh guru atau dosen dalam melaksanakan tugas keprofesionalan".

Kopetensi guru yang dijelaskan pada pasal 10 ayat 1 UU No. 14 Tahun 2005 meliputi kompetensi pedagogik, kepribadian, sosial, dan profesional. Salah satu kegiatan untuk dapat meningkatkan profesionalisme guru ialah melalui kegiatan pengembangan profesi guru. Unsur dari pengembangan keprofesian terdiri dari tiga macam, yaitu pengembangan diri, karya inovatif, dan publikasi ilmiah yang salah satunya ialah menulis karya tulis ilmiah berupa hasil penelitian. Ditambahkan bahwa Permen No. 16 Tahun 2009 menerangkan bahwa selain melaksanakan PBM, guru harus membuat KTI (Karya Tulis IImiah), artikel ilmiah, atau makalah yang semuanya memiliki bobot angka kredit masing-masing.

Kegiatan menulis hasil penelitian tidaklah hanya sebatas untuk meningkatkan angka kredit untuk kenaikan jabatan atau keperluan sertifikasi portofolio, tetapi dalam rangka meningkatkan kualitas pengelolaan kelas, kualitas pelayanan kepada peserta didik, dan juga meningkatkan profesionalisme guru itu sendiri (Jaedun, 2011).

Faktanya, dalam harian Kompas edisi Jumat 27 Maret 2009 menyebutkan bahwa guru-guru Pegawai Negeri Sipil di tingkat pendidikan dasar dan menengah sulit mencapai golongan pangkat di atas IVA karena kemampuan mereka kemampuan menulis mereka masih lemah (Kusumah, W. 2012 dalam https://www.kompasiana.com/wijayalabs/550e9aa0813311b52cbc6337/karya-tulisilmiah-jadi-kendala-kenaikan-pangkat-guru) .

Berlandaskan fakta dan data di atas maka penelitian ini mencari jawaban mengenai bagaimana keterampilan menulis laporan penelitian tindakan kelas (PTK) di Kecamatan Plered Kabupaten Purwakarta.

\section{METODE}

Metode penelitian ini menggunakan metode penelitian deskriptif kualitatif. Penelitian deskriptif kualitatif ditujukan untuk mendeskripsikan fenomena-fenomena yang ada, baik bersifat alamiah maupun rekayasa manusia yang lebih memperhatikan mengenai karakteristik, kualitas, keterkaitan antar kegiatan (Sukmadinata, 2011: 77). Subjek penelitian dalam penelitian ini ialah guru yang telah menjadi ASN di kecamatan Plered Kabupaten Purwakarta. Disebutkan bahwa dalam penelitian kualitatif, subjek sebagai narasumber atau partisipan, informan, teman dan guru dalam penelitian (Sugiyono, 2009: 216). Teknik pengumpulan data yang digunakan adalah wawancara, dokumentasi dan observasi. Analisis data dalam penelitian ini dilakukan empat tahap yaitu pengumpulan data, reduksi data, menyajikan data, dan ferifikasi dan penarikan kesimpulan, merujuk pada Mathew B. Milles dan A. Michael Huberman (2009: 16-21) sebagai berikut. 


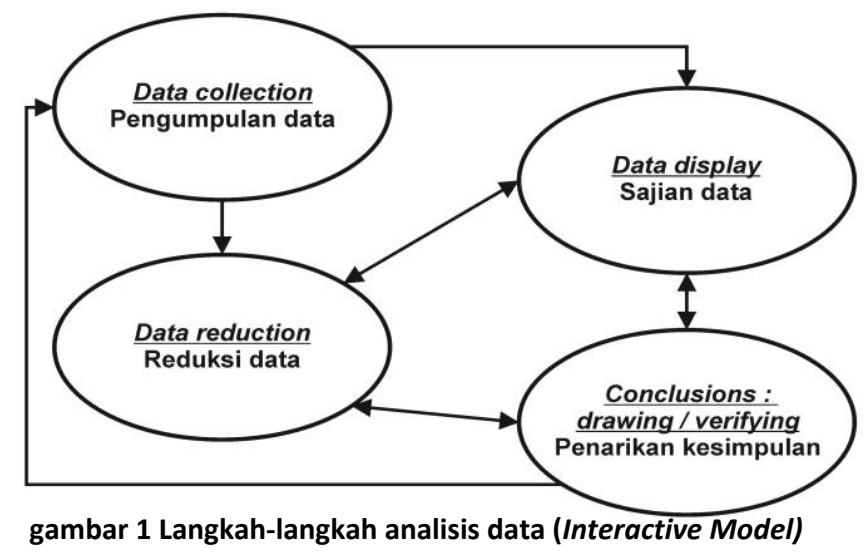

HASIL DAN PEMBAHASAN

Sesuai dengan tujuan penelitian, maka ditemukan hasil sebagai berikut.

\section{a. Keterampilan guru dalam menulis laporan penelitian tindakan kelas}

Secara umum, seluruh guru di Kecamatan Plered pernah membuat karya tulis ilmiah baik berupa makalah maupun skripsi yang merupakan prasyarat bagi tugas akhir belajar pada jenjang pendidikan yang ditempuh. Namun hal ini tidak menjamin para guru mampu dalam membuat laporan penelitian tindakan kelas. Terbukti dari hasil lembar kerja yang dibagikan selama penelitian, banyak yang masih tidak paham mengeni sistematika yang perlu ditulis pada sebuah laporan. Peneliti melihat bahwa hampir semua guru telah melakukan PTK, namun tidak mampu menuangkan dalam tulisan. Bahkan terdapat guru yang telah melakukan langkah-langkah PTK, namun mereka tidak sadar bahwa apa yang dilakukan ialah PTK. Lebih lanjut lagi ditemukan

\section{b. Hambatan guru dalam menulis laporan penelitian tindakan kelas}

Berdasarkan wawancara dan observasi terhadap guru ketika mengisi lembar kerja, terlihat bahwa ada beberapa hambatan yang ditemui oleh guru dalam menulis laporan penelitian tindakan kelas, yaitu

1. Pemahaman mengenai karya tulis ilmiah

Karya Ilmiah merupakan karya tulis disusun berdasarkan karangan, pernyataan, atau gagasan orang lain yang menyajikan data dan fakta hasil penelitian atau pengkajian. Ditulis menurut metode dan sistematika yang baik dan dapat dipertanggung-jawabkan (Yaniawati, 2018). Hampir semua guru di Kecamatan Plered memahami bahwa sebuah karya tulis ilmiah merupakan hasil sebuah penelitian, memiliki sistematika penulisan, dan tidak plagiat. Salah satu karya tulis ilmiah ialah berupa laporan penelitian. Adapun penelitian yang dapat dilakukan oleh guru ialah PTK (Penelitian Tindakan Kelas). Adapun selama ini ketika guru menemui permasalahan di kelas dan berusaha mencari jalan keluar untuk memecahkan permasalahn tersebut, guru telah melakukan PTK, namun karya tulis dapat dihasilkan, ketika guru menuangkan temuan dan data tersebut pada sebuah tulisan. Selanjutnya seorang guru mengungkapkan, bahwa karya ilmiah memerlukan landasan terori, bagian inilah yang dianggap sulit, yaitu mengaitkan antara teori dengan isi yang akan dibahas.

2. Pengetahuan sistematika penulisan

Pengetahuan akan sistematikan penulisan merupakan salah satu kunci dalam menulis sebuah karya ilmiah. Dari lembar kerja yang diberikan, guru masih bingung apa yang harus mereka tulis pada bagian latar belakang, rumusan masalah, metode dan bagian lainnya dari unsur sebuah laporan PTK.

3. Keterbatasan literatur

Keterbatasan mengenai sumber bahan rujukan baik berupa buku, jurnal maupun karya ilmiah lainnya membuat guru sulit untuk menulis baik karena 
keterbatasan bahasa maupun kutipan. Hal ini dapat dilihat ketika guru diminta untuk menuangkan ke dalam tulisan, permasalahan apa saja yang mereka temui di kelas, banyak lembar yang masih kosong. Diakui, bahwa mereka sulit untuk menuliskan apa yang ada dipikirannya, tapi lancar ketika harus menceritakan secara lisan. Ditelaah lebih jauh, bahwa guru masih belum mampu mencari sumber rujukan yang diperlukan melalui media internet, yang mana hal ini tentu menjadi sumber kendala selanjutnya.

4. Penggunakan Teknologi Komputer

Penggunaaan teknologi komputer untuk menunjang tugas para guru tidak banyak dimanfaatkan, hal ini dikarenakan kompetensi guru dalam pemanaatan teknologi tersebut kurang. Banyak guru di Kecamatan Plered mengakui, bahwa selain tidak adanya fasilitas tersebut, hal ini dikarenakan sulit dan lamanya guru untuk belajar menggunakan komputer. Pengoperasion komputer dari menghidupkan, memilih office yang akan digunakan, sampai mencari huruf di keyboard komputer membuat para guru kewalahan. Problematika guru dalam pemanfaatan teknologi ini sejalan dengan hasil temuan penelitian yang dilakukan oleh Nurhayati (2016) di salah satu sekolah Kabupaten Pati, dipaparkan bahwa beberapa alasan guru tidak memanfaatkan teknologi ialah tidak tersedianya fasilitas TIK, kemampuan guru di bidang TIK masih rendah dan tidak adanya pelatihanpelatihan guru untuk meningkatkan guru dalam bidang TIK.

5. Waktu

Hambatan yang paling dominan dan disuarakan paling lantang oleh guru ialah mengenai permasalahan waktu. Bahwa para guru menyebutkan, pembuatan Laporan Penelitian Tindakan Kelas membutuhkan waktu yang banyak, sedangkan para guru merasakan beban mengajar yang padat dan tuntutan administrasi yang tidak sedikit. Permasalahan pada segi waktu ini sesuai dengan temuan penelitian yang dilakukan Rahma Titi Larasati (2014) di Yogyakarya dan Ismi Danawati (2017) di Surakarta yang menyebutkan bahwa terbatasnya waktu dikarekanan tuntutan administrasi dan jam mengajar yang padat.

Pada dasarnya hambatan-hambatan di atas dapat diminimalisir oleh motivasi guru itu sendiri. As'ad (Cholis dan Wijono: 2014) motivasi seringkali diartikan dengan istilah dorongan. Dorongan atau tenaga tersebut merupakan jiwa dan jasmani untuk berbuat mencapai tujuan,sehingga motivasi merupakan suatu driving force yang menggerakan manusia untuk bertingkah laku,dan di dalam perbuatanya itu mempunyai tujuan tertentu. Adapun dorongan tersebut dapat tinbul dari dalam maupun luar diri pelaku. Dalam ilmu psikologi dikenal dengan istilah locus of control. Spector (Hendryadi, 2017: 418) menjelaskan bahwa lokus kontrol adalah keputusan individu untuk cenderung percaya dan bertanggung jawab terhadap kejadian sendiri berasal dari faktor internal (misalnya keterampilan, usaha, ketekunan) atau faktor eksternal (kesempatan, lain-lain, intervensi Tuhan). Individu yang memiliki lokus kendali internal memiliki keyakinan dan kesadaran bahwa mereka bertanggung jawab (mengontrol) keberhasilan dan kegagalan mereka. Sehingga seseorang dapat membangun keyakinan, usaha dengan menemukan cara untuk mencapai prestasi. Motivasi ekstrinsik pada diri guru tidak kalah penting, karena memiliki kekuatan untuk mengubah kemauan seseorang. Seseorang bisa berubah pikiran dari yang tidak mau menjadi mau berbuat sesuatu karena motivasi ini (Suhardi,2013). Pada dasarnya motivasi ekternal dalam menulis karya ilmiah telah ada, diantaranya peningkatan golongan, penambahan pendapatan. Namun motivasi eksternal dalam mengembangkan pengetahuan dalam penulisan karya ilmiah yang masih dirasa kurang, maka perlu adanya pelatihan yang lebih spesifik dalam mengembangkan bagian-bagian dari keterampilan menulis. Perlu diperlukan upaya dalam meningkatkan kompetensi profesional guru baik melalui seminar, pendidikan dan pelatihan, workshop, mengikut sertakan pada lomba-lomba. Hal ini perlu dukungan dari berbagai 
pihak baik kepala sekolah, dinas pendidikan sehingga guru memiliki sarana dan akses dalam mengembangkan keterampilan menulis karya ilmiah dan menumbuhkan motivasi untuk terus mengembangkan diri agar menjadi guru yang lebih profesional.

\section{SIMPULAN}

Berdasarkan hasil dan pembahasan di atas, maka dapat disimpulkan bahwa keterampilan menulis laporan penelitian tindakan kelas masih rendah dan sangat jarang dilakukan. Hal ini dikarenakan beberapa hambatan yang ditemui guru yaitu ketidak pahaman mengenai karya tulis ilmiah, pengetahuan sistematika penulisan yang rendah, keterbatasan lieteratur, kesulitan dalam penggunaan komputer, dan waktu. Namun dari itu semua bahwa yang menjadi akar hambatan yang ditemui oleh guru ialah motivasi.

\section{DAFTAR PUSTAKA}

Cholis dan Wijono. (2014). Pengaruh Motivasi Eksternal dan Motivasi Internal Terhadap Kinerja Karyawan pada TK Budi Mulia Dua Pandeansari. Jurnal MAKSIPRENEUR, Vol. III, No. 2, Hal. 1-15

Danawati. (2017). Problematika guru dalam menulis karya tulis ilmiah sebagai pengembangan kompetensi profesional di SD Muhammadiyah 5 Surakarta. [Online].Tersedia: http://eprints.ums.ac.id/50879/22/NASKAH\%20PUBLIKASI.pdf [diakses 22 Agustus 2019]

Hendyadi. (2017). Pengembangan Skala Locus of Control. Jurnal Riset Manajemen dan Bisnis (JRMB) Fakultas Ekonomi UNIAT. Vo. 2, No. Vol.2, No.3, Oktober 2017: $417-424$

Jaedun, A. (2011). Pengembangan Profesionalisme Guru Melalui Penulisan Karya Tulis IImiah. Makalah

http://staffnew.uny.ac.id/upload/131569339/pengabdian/karya-tulis-ilmiah-smkn1-sedayu.pdf

Kusumah, W. (2012). Karya Tulis IImiah Jadi Kendala Kenaikan Pangkat Guru. [Online]. $\quad$ Tersedia: https://www.kompasiana.com/wijayalabs/550e9aa0813311b52cbc6337/karyatulis-ilmiah-jadi-kendala-kenaikan-pangkat-guru [15 Agustus 2019]

Larasati, R. (2014). Faktor-faktor Penghambat Penulisan Karya Tulis IImiah dalam Pengembangan Keprofesian Berkelanjutan Guru Sekolah Dasar Negeri Lempuyangwangi Yogyakarta. Skripsi. PGSD UNY: Tidak diterbitkan

Miles, Matthew B. \& A. Michael Huberman. (2009). Analisis Data Kualitatif.Jakarta: UIPress.

Nurhayati, T. (2016). Problematika Guru dalam Menguasai TIK (Teknologi Informasi dan Komunikasi) Pada Pembelajaran Pendidikan Agama Islam dan Solusinya di MI Al-Asy'ari Kuniran Batangan Kabupaten Pati Tahun Ajaran 2015/2016. Skripsi. UNIVERSITAS ISLAM NEGERI WALISONGO SEMARANG: Tidak Diterbitkan

Sugiyono, (2009), Metode Penelitian Kuantitatif, Kualitatifdan R\&D, Bandung : Alfabeta.

Suhardi. (2013). The Science of Motivation (Kitab Motivasi). Jakarta: PT. GRAMEDIA

Sukmadinata, N.S. (2011). Metode Penelitian Pendidikan. Bandung: Remaja Rosadakarya

Yaniawati, P. (2018). Teknik Penulisan Karya Ilmiah. Sumedang: Disajikan pada Bimtek Penulisan Karya Ilmiah bagi Dosen PTS di Lingkungan Kopertis Wilayah IV. [Online]. Tersedia: https://www.kopertis4.or.id/wpcontent/uploads/2018/03/Prof.-Poppy-Teknik-Penulisan-Karya-IImiah-Poppypdf.pdf [diakses tanggal 2 Agustus 2019] 